\title{
Practitioners' perceptions of marketing: Field evidence from a Nordic country
}

Received: 30th April, 2007

\section{Øyvind Helgesen}

holds a Dr Oecon and is Associate Professor and Head of the Institute of International Marketing at Aalesund University College in Norway, where he has worked since 1993. He has previously worked for different service sector companies, first as a senior business advisor and later as director of finance and managing director. His teaching, work and research interests relate to marketing subjects and management accounting (corporate strategy, international marketing, market research, customer relationship management, etc). His papers have been published in the following journals: the British Food Journal, Corporate Reputation Review, Industrial Marketing Management, International Journal of Educational Management, Journal of Marketing Management and the Journal of Targeting, Measurement and Analysis for Marketing.

Keywords business performance, perceptions of marketing, profitability, the 'marketing concept'

Abstract Practitioners look upon marketing as a multidimensional tool. A questionnaire sent to Norwegian fishing and furniture industry marketers identified four factors (summated scales) based on 14 'marketing concept' items from the study. 'Reciprocity (Core)' was the only significant variable (summated scale) in a regression model explaining variations in business performance. 'Reciprocity (Core)' was not perceived as being particularly representative for marketing, suggesting that practitioners should perhaps rethink their perceptions of marketing, or at least the importance they attach to various marketing processes. The study also showed that profitability was neatly woven into practitioners' perceptions of the various dimensions (factors) of marketing, a finding that has implications both for the business world and for academia.

Journal of Targeting, Measurement and Analysis for Marketing (2007) 15, 181-194. doi:10.1057/palgrave.jt.5750048

\section{INTRODUCTION}

Marketing has been practiced since ancient times, ever since humankind discovered that specialisation of labour was an efficient way to satisfy basic needs such as food and clothing. The exchange of goods took place in central areas called markets. Over the centuries, the activities surrounding these exchanges have evolved into what we now call marketing. Thus, descriptions of marketing from hundreds of years ago are available from various historical sources. ${ }^{1-4}$

Academic interest in marketing first appeared about $1900 .{ }^{5-7}$ Since then, research efforts in the field have been on the increase, especially since

Correspondence: Øyvind Helgesen, Høgskolen i Ålesund,

Institutt for Internasjonal markedsføring (IIM),

Aalesund University College, Ålesund 6025, Norway.

Tel: + 70161218 ;

Fax: + 70161300

E-mail: oh@hials.no
1950, when the 'marketing concept' was introduced..$^{8-11}$ Over the last 30 years, new marketing related subject areas have been established and offered as a part of business school study programmes. Marketing can thus be seen as being based on various schools of marketing thought, covering a number of subject areas and approaches, and with various definitions. ${ }^{12-15}$ Marketing has also become more and more important in the worlds of both academia and business.

The purpose of this paper is to elucidate practitioners' perceptions of marketing. Through the use of a literature review, definitions of marketing and earlier studies focusing on the same research topic, a questionnaire was elaborated and sent to managers in the Norwegian furniture and fishing industries. Both industries are characterised by strong competition and extensive international activity (in terms of export and import volumes). In addition to 
measures of managers' perceptions of marketing, measures of business performance are also available. Therefore, the relationships between managers' perceptual measures of marketing and business performance have also been analysed, in order to provide additional insight.

\section{LITERATURE}

\section{The marketing concept}

The marketing concept is often related to the American company General Electric, which introduced it shortly after the Second World War. ${ }^{16,17}$ The basic philosophy was formulated in this way: 'Rather than making what you've always made, and then trying to sell it, find out what will sell, and then try to make it'. ${ }^{18}$ The marketing concept is, however, just one of the many ideas that are supposed to result in prosperity for firms. Other ideas are for example the production concept, the product concept, the selling concept and the societal marketing concept. ${ }^{19-21}$ The first three are seen as preceding the marketing concept, while the societal marketing concept is looked upon as an extension of the marketing concept. Different concepts may co-exist side by side within the same organisation, although normally one will dominate. It is common to talk about businesses as being production-oriented, sales-oriented or marketoriented, depending upon the company's dominant business logic. ${ }^{22-24}$ This suggests that market-oriented firms may be highly active in sales, for example, but with the logic of the marketing concept as the driving force behind these sales activities. ${ }^{25,26}$

In 1954, Drucker wrote one of the first descriptions of marketing: 'Actually marketing is so basic that it is not just enough to have a strong sales department and to entrust marketing to it. Marketing is not only much broader than selling; it is not a specialised activity at all. It encompasses the entire business. It is the whole business seen from the point of view of the final result that is from the customer's point of view. Concern and responsibility for marketing must therefore permeate all areas of the enterprise'. ${ }^{27}$
Subsequent to Drucker's work, researchers have debated various aspects of the marketing concept, such as its definition, its perception, its adoption by various industries and how it compared to other concepts. ${ }^{28}$ The 1990 s were particularly notable because of the increased attention that was devoted to implementing the marketing concept, that is to market orientation. ${ }^{29}$ The discussion continues today.

In 1959 Felton said that the 'marketing concept' could be understood as 'a corporate state of mind that insists on the integration and coordination of all the marketing functions which, in turn, are melded with all other corporate functions, for the basic objective of producing maximum long-range corporate profits' ${ }^{30}$ This way of thinking was supported by Levitt, ${ }^{31}$ who underscored the importance of 'building an effective customer-oriented company' and by McNamara, ${ }^{32}$ who defined the 'marketing concept' as 'a philosophy of business management, based upon a company-wide acceptance of the need for customer orientation, profit orientation and recognition of the important role of marketing in communicating the needs of the market to all major corporate departments'.

In 1970, Ames $^{33}$ underscored the importance of the marketing concept in industrial marketing (B2B): 'Rather, marketing in the industrial world is a total business philosophy aimed at improving profit performance by identifying the needs of each key customer group and then designing and producing a product/service package that will enable the company to serve selected groups more effectively than does the competition. This definition reveals four key dimensions to industrial marketing: (1) aiming for improved profit performance; (2) identifying customer needs; (3) selecting customer groups for whom the company can develop a competitive edge and (4) designing and producing the right product/ service package or packages'.

In 1992, Webster focused on 'the changing role of marketing in the corporation' and underlined the importance of marketing in strategy, 'reflecting three levels of strategy that can be defined as the corporate, the business or SBU, and functional or operating levels. ${ }^{34}$ A number of other contributions exist. ${ }^{35-40}$ 
Recently, the American Marketing Association (AMA) offered a new definition of marketing: 'Marketing is an organizational function and a set of processes for creating, communicating and delivering value to customers and for managing customer relationships in ways that benefit the organization and its stakeholders'. The last time the definition was revised was in $1985 .{ }^{41}$ At that time it had been unchanged for about 50 years. This new definition was officially unveiled at the AMA Summer Educators' Conference in Boston in August 2004. It implies a duality, that is satisfying customers by meeting their needs, desires and requests, and satisfying the business unit by exchanges that result in long-term relationships and profitability. Thus the focus is both on creating customer values and economic customer values. ${ }^{42,43}$ This duality with respect to customers and businesses also appears in the definition of the UK Chartered Institute of Marketing: 'Marketing is the management process which identifies, anticipates, and supplies customer requirements efficiently and profitably'. ${ }^{44,45}$

The most cited 'Nordic School' definition of marketing is offered by Grönroos, which states that marketing is 'to identify and establish, maintain and enhance and, when necessary, terminate relationships with customers, and other stakeholders, at a profit so that the objectives of all parties involved are met; this is done by mutual exchange and fulfilment of promises'. ${ }^{46}$ According to the 'Nordic School', relationship marketing is very important for obtaining longterm customer satisfaction and customer loyalty as well as long-term customer profitability. This implicitly highlights the importance of marketing metrics both from the point of view of the customers and from the point of view of the managers and the marketers of a business unit, that is 'customer-based' and 'business-unit-based' marketing metrics. ${ }^{47,48}$

Thus, the marketing concept has been discussed at length in many publications for many years, and has been described and defined in different ways. Nevertheless, the various approaches have much in common. The most important ingredients of the marketing concept may be summarised with phrases like: customers' needs, desires and demands; customer values; customer orientation; market orientation; customer relationships; long-term relationships; customer satisfaction; customer loyalty; customer profitability; long-term profitability; reciprocity that is both customer satisfaction from need fulfilment and firm satisfaction from customer profitability; mutual trust by keeping promises; ethical attitudes; customer- and market-oriented leadership and organisational culture. There also seems to be a common understanding that the application of the concept involves both an analytical process (strategic marketing) and an action-oriented process (operational marketing). ${ }^{49}$ This implies that the marketing concept forms a natural basis for various strategic considerations within a firm, such as developing mission statements, visions and the like.

\section{Business performance}

Business performance is closely related to profitability. ${ }^{50,51}$ The point of departure for business-oriented approaches is decision-relevant revenues and costs, that is changes in revenues and costs resulting from a decision. This traditional business view, based on purely financial indicators, is often regarded as rather narrow and has been challenged by other approaches.

One approach proposes a classification of performance measures according to different organisational levels: (1) financial performance, focusing on purely financial indicators; (2) business performance, where noneconomic indicators such as market share, product development or production efficiency are incorporated and (3) organisational effectiveness, where a number of various metrics are considered. ${ }^{52,53}$ This way of thinking forms the basis for newer approaches to performance measurements such as 'Balanced Scorecards' 54,55 and 'Business Models ${ }^{56,57}$ where both 'objective' and 'perceptual' ('subjective') measures are considered. By including metrics such as customer satisfaction, customer loyalty, co-worker satisfaction, organisational learning, etc one may be able to monitor the future of the business unit, as the metrics may be regarded as antecedents of future financial performance, or, 'leading metrics' 
as opposed to financial key figures, which are 'lagging metrics'. ${ }^{58,59}$

The overall performance of a business unit may also be measured by using perceptual metrics. Subjective measures may comprise factors, aspects or relationships that are not included in their objective counterparts. Summarised measures of business performance based on subjective interpretations or judgments by firm leaders may, in many instances, give a better indication of business performance than purely objective indicators can. ${ }^{60-62}$

\section{METHODOLOGY}

Identifying practitioners' perceptions of marketing requires empirical data. The context of this study is the Norwegian furniture and fishing industries. In both industries, business units market products for consumption, with furniture classified as durables and fish products as nondurables. Both industries are characterised by strong competition and substantial international activity (in terms of export and import volumes).

The literature review shows that many questions would be relevant in a survey designed to study practitioners' perception of marketing. Based on discussions with business people and academics, however, a final list was elaborated. It should be underscored that even with a comprehensive and systematic review of the literature, item selection can necessarily have been influenced by the 'Nordic School', as is reflected in the title of this paper. When deciding the final number of items, the number of responses anticipated was taken into consideration (conclusive validity). Table 2 shows the 14 items of the study. This part of the questionnaire was presented as a seven-point Likert scale with 1 implying 'Strongly disagree' and 7 implying 'Strongly agree'.

Elsewhere in the questionnaire, respondents were asked to give their total appraisal of the performance of their firm during the last three years compared with the performance of their competitors. A seven-point semantic differential scale was used, where -3 meant 'Worse than competitors', 0 (zero) meant 'About the same as competitors' and +3 'Better than competitors'.
This approach for measuring 'Overall corporate performance' is in accordance with recommendations from analogous studies. ${ }^{63-65}$ In addition, respondents were asked to report the following financial key figures: average yearly sales growth during the last three years (per cent) ('sales growth'), average yearly surplus rate during the last three years (per cent) ('surplus rate') and average yearly return on capital employed (ROCE) during the last three years (per cent) ('ROCE'). These figures may be regarded as objective performance measures and can be used to validate the perceptual measure 'Overall corporate performance', cf. Table 7 and the discussion below.

In order to make the paper easier to read, all perceptual items have been presented on a scale from 0 (zero) to 100 , so that for the 14 Likertscale items, 1 is equal to 0 (zero) and 7 equal to 100. For the one semantic scale item, -3 is thus equal to 0 (zero) and +3 equal to 100 . The three financial key figures (per cent) are ratio-level measures.

Questionnaires were mailed to managers of 360 firms, of which 225 were associated with the fishery industry and 135 with the furniture industry. The sample was selected from industry registers. Fifteen unanswered questionnaires were returned, because the companies were no longer in business. Reminders were sent twice, with the reminder interval about one month. Of a total of 137 answers, ten reported that the questionnaire was of little relevance. Thus the final sample consists of 127 respondents, of which 74 were from the fishing industry and 53 from the furniture industry. This gives a response rate of 38 per cent. Disregarding incomplete answers, the response rate is 35 per cent. Total turnover for the firms in the sample was NOK 20bn for the fishery sector and NOK $3 \mathrm{bn}$ for the furniture sector. This indicates that the sample represented approximately 60 per cent of the total turnover in the Norwegian fishery sector and 40 per cent of the total turnover in the Norwegian furniture sector.

Table 1 presents descriptive statistics for the survey sample. A total of 118 of the 127 respondents answered all relevant questions. 
Table 1: Descriptive statistics for the study sample

\begin{tabular}{|c|c|c|c|c|}
\hline Industry and variables & Mean & SD & Skewness & Kurtosis \\
\hline \multicolumn{5}{|l|}{ Fishing industry $(n=69)$} \\
\hline $\begin{array}{l}\text { Total revenue previous year (Million Norwegian Kroner) } \\
\text { (NOK) }\end{array}$ & 313.7 & 674.7 & 5.5 & 35.1 \\
\hline Average number of employees previous year & 127.1 & 433.0 & 7.2 & 56.1 \\
\hline Proportion of exports (\%) & 71.1 & 32.5 & -1.2 & -0.1 \\
\hline \multicolumn{5}{|l|}{ Furniture industry $(n=49)$} \\
\hline $\begin{array}{l}\text { Total revenue previous year (Million Norwegian Kroner) } \\
\text { (NOK) }\end{array}$ & 60.6 & 107.9 & 3.9 & 16.2 \\
\hline Average number of employees previous year & 60.3 & 101.0 & 4.1 & 18.0 \\
\hline Proportion of exports (\%) & 13.4 & 17.7 & 1.5 & 2.1 \\
\hline \multicolumn{5}{|l|}{ Sample of the survey $(n=118)$} \\
\hline $\begin{array}{l}\text { Total revenue previous year (Million Norwegian Kroner) } \\
\text { (NOK) }\end{array}$ & 208.5 & 533.9 & 6.9 & 56.9 \\
\hline Average number of employees previous year & 99.3 & 338.0 & 9.0 & 89.4 \\
\hline Proportion of exports (\%) & 47.2 & 39.4 & 0.1 & -1.7 \\
\hline
\end{tabular}

On the average, business units in the fishing industry were bigger than business units in the furniture industry, based on a comparison of total revenues in the previous year and the average number of employees in the previous year for the two industries. Additionally, the fishing industry's proportion of exports (per cent) and spread was much higher than the furniture industry's.

\section{RESULTS}

\section{Descriptive statistics for 'marketing concept' variables}

Table 2 presents descriptive statistics for the 14 'marketing concept' variables or items that were included in the study. A total of 116 of the 127 respondents answered all the questions of this part of the questionnaire.

Table 2 shows that the respondents' evaluations of the 14 statements $\left(I_{1}-I_{14}\right)$ vary, as measured by their means. The standard deviations (SD) are approximately the same for all 14 items, demonstrating that no item stands out from the rest with respect to spread. The same conclusion can be drawn regarding skewness and kurtosis.

The mean of each of the items is a measure of the average level of agreement among the managers regarding the particular statement (item). The closer the average is to 100 , the greater the general agreement that the item 'represents' marketing (the 'marketing concept'). Thus, the following five statements were perceived as having the closest relationship with the 'marketing concept': 'Marketing is a collective term for all efforts to increase sales volume' $\left(\mathrm{I}_{4}\right)$, 'Regarding marketing, the focus is on developing long-term customer relationships' $\left(\mathrm{I}_{13}\right)$, 'Marketing implies reciprocity, ie both buyer and seller should be satisfied (buyer in terms of customer satisfaction and seller in terms of customer profitability)' $\left(\mathrm{I}_{9}\right)$, 'Marketing implies trustbuilding (in relationships) by keeping promises' $\left(\mathrm{I}_{11}\right)$ and 'Marketing implies more focus on longterm profitability than short-term profits' $\left(\mathrm{I}_{14}\right)$. For all the five items, the mean is approximately in the 70-75 interval on a scale from 0 to 100 .

Four statements have averages ranging from 48 to 52; these were: 'Marketing implies that more importance is attached to profitability than to sales volume' $\left(\mathrm{I}_{10}\right)$, 'In practicality, there is no difference between marketing and sales' $\left(I_{2}\right)$, 'Marketing has a stronger ethical basis than sales' $\left(\mathrm{I}_{12}\right)$ and 'What theorists call marketing, practitioners call sales' $\left(I_{8}\right)$. These items were not perceived as being that 'representative' for the 'marketing concept'.

The means of the other five statements are between the two other groups of items and ranged from about 57 to 65 ; these were: 'Marketing, market orientation and customer 
Table 2: Descriptive statistics for the 14 items related to the marketing concept $(n=116)$

\begin{tabular}{|c|c|c|c|c|c|}
\hline Items (variables) & Symbol & Mean & SD & Skewness & Kurtosis \\
\hline $\begin{array}{l}\text { Marketing is closely related to corporate strategy, for } \\
\text { example mission, vision, business ideas and business } \\
\text { philosophy }\end{array}$ & $\mathrm{l}_{1}$ & 65.38 & 23.00 & -0.65 & 0.63 \\
\hline $\begin{array}{l}\text { In practicality, there is no difference between marketing and } \\
\text { sales }\end{array}$ & $\mathrm{I}_{2}$ & 48.28 & 27.31 & 0.21 & -0.78 \\
\hline $\begin{array}{l}\text { Marketing is a business function parallel to, for example, } \\
\text { purchase and production }\end{array}$ & $\mathrm{I}_{3}$ & 65.23 & 25.02 & -0.76 & -0.04 \\
\hline $\begin{array}{l}\text { Marketing is a collective term for all efforts to increase sales } \\
\text { volume }\end{array}$ & $\mathrm{I}_{4}$ & 75.00 & 23.10 & -1.28 & 1.76 \\
\hline Marketing is closely related to profitability & $\mathrm{I}_{5}$ & 63.36 & 24.40 & -0.50 & -0.29 \\
\hline $\begin{array}{l}\text { Marketing, market orientation and customer orientation are } \\
\text { synonymous concepts }\end{array}$ & $I_{6}$ & 56.90 & 28.15 & -0.22 & -0.89 \\
\hline $\begin{array}{l}\text { Marketing is closely related to customer satisfaction, } \\
\text { customer loyalty and customer profitability }\end{array}$ & $\mathrm{I}_{7}$ & 61.78 & 22.42 & -0.17 & -0.40 \\
\hline What theorists call marketing, practitioners call sales & $\mathrm{I}_{8}$ & 52.44 & 27.39 & 0.01 & -0.65 \\
\hline $\begin{array}{l}\text { Marketing implies reciprocity, that is both buyer and seller } \\
\text { should be satisfied (buyer in terms of customer satisfaction } \\
\text { and seller in terms of customer profitability) }\end{array}$ & $\mathrm{l}_{9}$ & 70.83 & 22.08 & -0.43 & -0.57 \\
\hline $\begin{array}{l}\text { Marketing implies that more importance is attached to } \\
\text { profitability than to sales volume }\end{array}$ & $\mathrm{I}_{10}$ & 48.28 & 25.95 & 0.05 & -0.54 \\
\hline $\begin{array}{l}\text { Marketing implies trust-building (in relationships) by keeping } \\
\text { promises }\end{array}$ & $\mathrm{I}_{11}$ & 70.55 & 23.61 & -1.06 & 1.23 \\
\hline Marketing has a stronger ethical basis than sales & $\mathrm{l}_{12}$ & 51.87 & 27.70 & -0.22 & -0.69 \\
\hline $\begin{array}{l}\text { Regarding marketing, the focus is on developing long-term } \\
\text { customer relationships }\end{array}$ & $l_{13}$ & 72.56 & 23.49 & -1.09 & 1.19 \\
\hline $\begin{array}{l}\text { Marketing implies more focus on long-term profitability than } \\
\text { short-term profits }\end{array}$ & $\mathrm{I}_{14}$ & 69.54 & 25.75 & -1.03 & 0.95 \\
\hline
\end{tabular}

orientation are synonymous concepts' $\left(\mathrm{I}_{6}\right)$,

'Marketing is closely related to customer satisfaction, customer loyalty and customer profitability' $\left(\mathrm{I}_{7}\right)$, 'Marketing is closely related to profitability' $\left(\mathrm{I}_{5}\right)$, 'Marketing is a business function parallel to eg purchase and production' $\left(\mathrm{I}_{3}\right)$ and 'Marketing is closely related to corporate strategy, eg mission, vision, business ideas and business philosophy $\left(\mathrm{I}_{1}\right)$.

The sample consisted of respondents from two industries: the furniture industry (48 respondents) and fishing industry (68 respondents). $T$-tests do not reveal any significant differences $(p<0.05)$ for any one of the 14 items. Analogous $t$-tests were calculated for groups of respondents according to revenue figures in the previous year, average number of employees in the previous year and proportions of exports. For all the three variables, two groups, consisting of approximately the same number of respondents, were established and $t$-tests conducted. The $t$-tests did not reveal any significant differences $(p<0.05)$ for any one of the 14 items. Thus, the results can be perceived as representing both industries.

\section{Factor analysis of the 'marketing concept' variables}

The 14 items in this study are assumed to be linked in the minds of the respondents. Factor analyses are often conducted to identify the dimensionality (the factors) of the items as well as the relationships (the factor loadings) of each of the factors for each of the items (data summarisation). This insight regarding the respondents' grouping of items can be used in various ways, for example to improve the questionnaire by excluding items with low factor loadings and to include new ones. Factor analyses also imply that the findings can be presented in a condensed manner (data reduction), thus giving more insight into the information than might have been obtained by only studying individual items as discussed above.

In order to work out factor analyses for a data set, certain requirements have to be met with respect to the absolute number of cases, the number of cases per item, the level of the correlation coefficients between items and their significance levels as well as the overall measures 
of intercorrelation. ${ }^{66}$ The number of cases in this study is higher than 100 and about eight per item, both of which are satisfactory. Table 3 shows the correlation matrix between the 14 items $\left(\mathrm{I}_{1}-\mathrm{I}_{14}\right)$ based on Pearson's linear correlation coefficients. Coefficients above (about) 0.18 are significant at the 0.05 level (two-tailed), those above 0.24 at the 0.01 level and those above 0.30 at the 0.001 level. About one-third of the correlation coefficients are larger than 0.3 and about one-half significant at the 0.05 level at least. The MSA (Kaiser-Meyer-Olkin Measure of Sampling Adequacy) has a value of 0.73 , which is also satisfactory. A principal components analysis (varimax rotation) was calculated for the 14 items. Table 4 presents the factor loadings for a fourfactor analysis of the 14 items 'representing' the marketing concept, Table 5 gives descriptive statistics for the four factors and Table 6 presents correlation matrix for the four factors, as well as measures of reliability and validity.

In Table 4, the items have been sorted according to decreasing factor loadings. All factor loadings above approximately 0.51 are significant at the 0.05 level. ${ }^{67}$ The first two variables (summated scales) of the four-factor model each consist of four items, while the next two variables consist of three items. The four summated scales are called 'Long-term focus' $\left(\mathrm{F}_{1}\right)$, 'Reciprocity (Core)' $\left(\mathrm{F}_{2}\right)$, 'Marketing as sales' $\left(\mathrm{F}_{3}\right)$ and 'Strategy and function' $\left(\mathrm{F}_{4}\right)$. Table 5 shows that 'Long-term focus' $\left(F_{1}\right)$ and 'Strategy and function' $\left(F_{4}\right)$ were perceived as more closely 'representing' the 'marketing concept' than 'Reciprocity (Core)' $\left(\mathrm{F}_{2}\right)$ and 'Marketing as sales' $\left(\mathrm{F}_{3}\right)$. The differences between the means were, however, not very large. $T$-tests were also carried out for two groups consisting of the two industries, revenue figures previous year, average number of employees previous year and proportions of exports. The $T$-tests did not reveal any significant differences $(p<0.05)$ for any of the four new variables (summated scales).

Table 6 shows that Cronbach's alpha was satisfactory for only one of the four new variables, that is 0.7 or higher. For two of the other three variables, however, Cronbach's alpha was close to 0.7 . For $\left(\mathrm{F}_{4}\right)$, the statistic only had a value of 0.57. The Variance Extracted (VE) measure exceeded the recommended level of 0.5 for all four variables. Thus convergent validity can be claimed for all four variables. Discriminant validity was examined by comparing the VE measure for each of the new variables with the square of the correlation coefficients between the variable considered and each of the other variables in Table 6 . In order to have a construct be considered truly distinct from another construct, the VE measure should be larger than the square of each of the correlation coefficients. Table 6 contains the information necessary to explore this. The highest shared variance is 0.17 (0.41 squared), found between 'Long-term focus' $\left(\mathrm{F}_{1}\right)$ and 'Reciprocity (Core)' $\left(\mathrm{F}_{2}\right)$, and also between 'Reciprocity (Core)' $\left(\mathrm{F}_{2}\right)$ and 'Strategy and function' $\left(\mathrm{F}_{4}\right)$. This is far from the four VE measures. Thus also discriminant validity may be claimed for all the four summated scales. Other items from the questionnaire were used to validate the findings and support the choice of names of the new variables (summated scales).

\section{Business performance}

Table 7 presents descriptive statistics for the four performance measures included in the survey: total appraisal of corporate performance during the last three years compared with competitors ('overall corporate performance'), average yearly sales growth during the last three years (per cent) ('sales growth'), average yearly surplus rate during the last three years (per cent) ('surplus rate') and average yearly ROCE during the last three years (per cent) ('ROCE'). A total of 121 respondents answered the question regarding 'overall corporate performance'. The mean value of managers' perceived 'overall corporate performance' was 64.5 on a scale from 0 to 100 . This measure was used as the dependent variable of a regression model as discussed below. The other three measures were considered to be 'objective' measures and were used to validate the 'overall performance' measure. 'Sales growth' data were provided by 95 firms. On average, 'sales growth' was about 34.9 per cent during the last three years. Eighty-four firms provided their 'surplus 
装: Helgesen

Table 3: Correlation matrix (Pearson's linear correlation coefficients) of the 14 items related to the marketing concept $(n=116)$

\begin{tabular}{|c|c|c|c|c|c|c|c|c|c|c|c|c|c|c|}
\hline & $I_{1}$ & $I_{2}$ & $I_{3}$ & $I_{4}$ & $I_{5}$ & $I_{6}$ & $I_{7}$ & $I_{8}$ & $I_{9}$ & $I_{10}$ & $I_{11}$ & $I_{12}$ & $I_{13}$ & $I_{14}$ \\
\hline $\mathrm{I}_{1}$ & 1.00 & & & & & & & & & & & & & \\
\hline $\mathrm{I}_{2}$ & 0.08 & 1.00 & & & & & & & & & & & & \\
\hline $\mathrm{I}_{3}$ & 0.31 & 0.17 & 1.00 & & & & & & & & & & & \\
\hline $\mathrm{I}_{4}$ & 0.10 & 0.34 & 0.30 & 1.00 & & & & & & & & & & \\
\hline$I_{5}$ & 0.29 & 0.12 & 0.32 & 0.07 & 1.00 & & & & & & & & & \\
\hline$I_{6}$ & 0.24 & 0.19 & 0.31 & 0.19 & 0.39 & 1.00 & & & & & & & & \\
\hline $\mathrm{I}_{7}$ & 0.11 & 0.15 & 0.14 & -0.06 & 0.34 & 0.44 & 1.00 & & & & & & & \\
\hline $\mathrm{I}_{8}$ & -0.09 & 0.54 & 0.13 & 0.30 & -0.07 & 0.24 & 0.12 & 1.00 & & & & & & \\
\hline$I_{9}$ & 0.24 & -0.01 & 0.03 & -0.05 & 0.14 & 0.25 & 0.38 & 0.11 & 1.00 & & & & & \\
\hline$I_{10}$ & 0.21 & 0.06 & 0.16 & 0.04 & 0.21 & 0.35 & 0.39 & 0.05 & 0.35 & 1.00 & & & & \\
\hline $\mathrm{I}_{11}$ & 0.01 & 0.06 & 0.17 & 0.02 & 0.39 & 0.37 & 0.39 & 0.17 & 0.23 & 0.20 & 1.00 & & & \\
\hline $\mathrm{I}_{12}$ & 0.15 & 0.01 & 0.05 & -0.01 & 0.12 & 0.10 & 0.09 & -0.02 & 0.10 & 0.11 & 0.33 & 1.00 & & \\
\hline $\mathrm{l}_{13}$ & 0.40 & -0.01 & 0.21 & 0.10 & 0.41 & 0.31 & 0.38 & 0.01 & 0.40 & 0.21 & 0.53 & 0.31 & 1.00 & \\
\hline $\mathrm{I}_{14}$ & 0.14 & 0.05 & 0.11 & 0.03 & 0.32 & 0.16 & 0.34 & -0.08 & 0.15 & 0.09 & 0.44 & 0.39 & 0.53 & 1.00 \\
\hline
\end{tabular}

Table 4: Factor loadings for a four-factor analysis of the 14 items related to the marketing concept $(n=116)$

\begin{tabular}{|c|c|c|c|c|c|}
\hline Items (variables) & Symbol & $\begin{array}{l}\text { Long-term } \\
\text { focus }\left(F_{1}\right)\end{array}$ & $\begin{array}{l}\text { Reciprocity } \\
\text { (Core) }\left(F_{2}\right)\end{array}$ & $\begin{array}{l}\text { Marketing } \\
\text { as sales }\left(F_{3}\right)\end{array}$ & $\begin{array}{l}\text { Strategy and } \\
\text { function }\left(F_{4}\right)\end{array}$ \\
\hline $\begin{array}{l}\text { Marketing implies more focus on long-term profitability than } \\
\text { short-term profits }\end{array}$ & $\mathrm{I}_{14}$ & 0.81 & & & \\
\hline $\begin{array}{l}\text { Marketing implies trust-building (in relationships) by keeping } \\
\text { promises }\end{array}$ & $\mathrm{I}_{11}$ & 0.72 & & & \\
\hline Marketing has a stronger ethical basis than sales & $\mathrm{I}_{12}$ & 0.67 & & & \\
\hline $\begin{array}{l}\text { Regarding marketing, the focus is on developing } \\
\text { long-term customer relationships }\end{array}$ & $\mathrm{I}_{13}$ & 0.65 & & & \\
\hline $\begin{array}{l}\text { Marketing implies reciprocity, that is both buyer and seller } \\
\text { should be satisfied (buyer in terms of customer satisfaction } \\
\text { and seller in terms of customer profitability) }\end{array}$ & $l_{9}$ & & 0.72 & & \\
\hline $\begin{array}{l}\text { Marketing is closely related to customer satisfaction, } \\
\text { customer loyalty and customer profitability }\end{array}$ & $\mathrm{I}_{7}$ & & 0.72 & & \\
\hline $\begin{array}{l}\text { Marketing implies that more importance is attached to } \\
\text { profitability than to sales volume }\end{array}$ & $\mathrm{l}_{10}$ & & 0.70 & & \\
\hline $\begin{array}{l}\text { Marketing, market orientation and customer orientation are } \\
\text { synonymous concepts }\end{array}$ & $I_{6}$ & & 0.55 & & \\
\hline What theorists call marketing, practitioners call sales & $\mathrm{I}_{8}$ & & & 0.83 & \\
\hline $\begin{array}{l}\text { In practicality, there is no difference between marketing and } \\
\text { sales }\end{array}$ & $\mathrm{I}_{2}$ & & & 0.79 & \\
\hline $\begin{array}{l}\text { Marketing is a collective term for all efforts to increase sales } \\
\text { volume }\end{array}$ & $\mathrm{I}_{4}$ & & & 0.61 & \\
\hline $\begin{array}{l}\text { Marketing is closely related to corporate strategy, for } \\
\text { example, mission, vision, business ideas and business } \\
\text { philosophy }\end{array}$ & $\mathrm{l}_{1}$ & & & & 0.76 \\
\hline $\begin{array}{l}\text { Marketing is a business function parallel to, for example, } \\
\text { purchase and production }\end{array}$ & $\mathrm{I}_{3}$ & & & & 0.71 \\
\hline Marketing is closely related to profitability & $\mathrm{I}_{5}$ & & & & 0.51 \\
\hline
\end{tabular}

Table 5: Descriptive statistics for the four factors $(n=116)$

\begin{tabular}{|c|c|c|c|c|c|}
\hline Factors (variables) & Symbol & Mean & SD & Skewness & Kurtosis \\
\hline Long-term focus & $\mathrm{F}_{1}$ & 66.13 & 18.84 & -0.69 & 1.19 \\
\hline Reciprocity (Core) & $\mathrm{F}_{2}$ & 59.45 & 17.80 & 0.11 & -0.02 \\
\hline Marketing as sales & $\mathrm{F}_{3}$ & 58.57 & 20.11 & -0.21 & 0.11 \\
\hline Strategy and function & $\mathrm{F}_{4}$ & 64.66 & 17.73 & -0.65 & 1.22 \\
\hline
\end{tabular}


Table 6: Correlation matrix for the four factors as well as measures of reliability and validity $(n=116)$

\begin{tabular}{|c|c|c|c|c|}
\hline Factors (variables) & $\begin{array}{l}\text { Long-term focus } \\
\left(F_{1}\right)\end{array}$ & $\begin{array}{l}\text { Reciprocity (Core) } \\
\left(\mathrm{F}_{2}\right)\end{array}$ & $\begin{array}{l}\text { Marketing as sales } \\
\left(F_{3}\right)\end{array}$ & $\begin{array}{l}\text { Strategy and function } \\
\left(F_{4}\right)\end{array}$ \\
\hline Long-term focus & 1.00 & & & \\
\hline Reciprocity (Core) & 0.41 & 1.00 & & \\
\hline Marketing as sales & 0.04 & 0.17 & 1.00 & \\
\hline Strategy and function & 0.37 & 0.41 & 0.16 & 1.00 \\
\hline Cronbach's alpha (CA) & 0.74 & 0.69 & 0.66 & 0.57 \\
\hline Variance extracted (VE) & 0.57 & 0.52 & 0.59 & 0.54 \\
\hline
\end{tabular}

Table 7: Descriptive statistics for the four measures of performance

\begin{tabular}{|c|c|c|c|c|c|}
\hline Items (variables) & $n$ & Mean & SD & Skewness & Kurtosis \\
\hline $\begin{array}{l}\text { A total appraisal of corporate performance during the last } \\
\text { three years compared with competitors ('overall corporate } \\
\text { performance') }\end{array}$ & 121 & 64.46 & 16.93 & -0.31 & 0.05 \\
\hline $\begin{array}{l}\text { Average yearly sales growth during the last three years (\%) } \\
\text { ('sales growth') }\end{array}$ & 95 & 34.85 & 93.98 & 8.51 & 78.39 \\
\hline $\begin{array}{l}\text { Average yearly surplus rate during the last three years (\%) } \\
\text { ('surplus rate') }\end{array}$ & 84 & 7.49 & 12.16 & 5.76 & 41.20 \\
\hline $\begin{array}{l}\text { Average yearly return on capital employed (ROCE) during } \\
\text { the last three years (\%) ('ROCE') }\end{array}$ & 54 & 14.03 & 16.66 & 3.43 & 14.75 \\
\hline
\end{tabular}

rate'. On average, the 'surplus rate' was about 7.5 per cent during the last three years. Fifty-four firms provided information about their 'ROCE'. On average, 'ROCE' was about 14.0 per cent during the last three years. The variance of 'sales growth' was much larger than the variances of the other three measures.

Pearson's linear correlation coefficient between 'overall corporate performance' and 'sales growth' was significant $(r=0.17 ; p<0.05)$, as were the relationships between 'overall corporate performance' and 'surplus rate' $(r=0.19 ; p<0.05)$ and 'overall corporate performance' and 'ROCE' $(r=0.32 ; p<0.05)$. With respect to the strength of the relationship between two variables, Cohen ${ }^{68}$ suggests the following guidelines: $r=0.10-0.29$ : small; $r=0.30-0.49$ : medium and $r=0.50-1.00$ : large. Thus, the strength of the linear relationship is small for the first two coefficients and medium for the last. The greatest weight should be given to the relationship between 'overall corporate performance' and 'ROCE'. Thus the results can be seen as validating the measure termed 'overall corporate performance'.

\section{Perceptions of marketing - Business performance}

Managers' perceptual measures of marketing can be taken as explanatory variables of variations of business performance. The four variables (summated scales) discussed above were thus used as independent variables in a regression model where 'overall corporate performance' is the dependent variable. Other independent variables were included in order to validate the findings.

One hundred and thirteen of the 116 respondents answered all the relevant items in the questionnaire. A normality test of the residual is satisfactory (KolmogorovSmirnov $=0.06 ; p \geqslant 0.20)$, implying that one cannot say that the residual is not normally distributed. In addition, other important model statistics are satisfactory, eg regarding collinearity and outliers.

Table 8 presents estimates of the regression coefficients and $t$-values. Other important statistics are: $R_{\text {adj. }}^{2}=0.07 ; F=3.21 \quad(p<0.05)$. According to these findings, the model as a 
whole (the regression equation) was significant at the 0.05 level. The variations in the four independent variables, however, explained only about 7 per cent of the variance of 'overall corporate performance'. The regression equation is:

$\begin{array}{ll}\text { 'Overall } & +43.21+0.14 \text { 'Long-term focus' } \\ \text { corporate } & +0.22 \text { 'Reciprocity (Core)' } \\ \text { performance': } & -0.03 \text { 'Marketing as sales' } \\ & +0.01 \text { 'Strategy and function' }\end{array}$

The coefficient estimates explained the partial effects of each variable included in the equation. Only one of the coefficient estimates, 'Reciprocity (Core)', was significant $(p<0.05)$. The other three coefficient estimates are also of interest because they form a part of the regression model.

Various regression models were introduced to explain variations in 'Overall corporate performance'. In the most extensive model the following independent variables were included in addition to the four variables above: total revenue in the previous year, average number of workers in the previous year, proportion of exports (per cent) and industry ('dummy'). A normality test of the residual was satisfactory (KolmogorovSmirnov $=0.08 ; p \geqslant 0.14)$. In addition, other important model statistics are satisfactory, for example regarding collinearity and outliers. The model was significant at the 0.05 level. The variations in the eight independent variables explained only about 7 per cent of the variance of 'overall corporate performance', or the same as the regression model discussed above. Even more interesting, 'Reciprocity (Core)' was the only variable that was significant $(p<0.05)$, with the coefficient estimate approximately the same as presented in Table 8 .

\section{DISCUSSION AND CONCLUSION}

Managers from 127 Norwegian companies responded to questionnaires for this study. The sample consisted of 74 firms from the fishing industry and 53 from the furniture industry. The response rate was 38 per cent. Total turnover for the firms in the sample was about NOK 20bn for the fishery industry and about NOK 3 bn for the furniture industry. This implies that the sample represented approximately 60 per cent of the total
Table 8: Estimates of regression coefficients and $t$-values $(n=113)$

\begin{tabular}{llcc}
\hline $\begin{array}{l}\text { Variables (concept/ } \\
\text { items/factors) }\end{array}$ & Symbol & $\begin{array}{l}\text { Regression } \\
\text { coefficients }\end{array}$ & $\boldsymbol{t}$ \\
\hline Constant & & 43.21 & $5.42^{\mathrm{a}}$ \\
Long-term focus & $\mathrm{F}_{1}$ & 0.14 & 1.53 \\
Reciprocity (Core) & $\mathrm{F}_{2}$ & 0.22 & $2.17^{\mathrm{b}}$ \\
Marketing as sales & $\mathrm{F}_{3}$ & -0.03 & -0.35 \\
Strategy and function & $\mathrm{F}_{4}$ & 0.01 & 0.06 \\
\hline$p<0.001$. & & & \\
$p<0.05$. & & &
\end{tabular}

turnover of the Norwegian fishery industry and 40 per cent of the Norwegian furniture industry. It should be underscored that even with a comprehensive and systematic review of the literature, item selection may have been influenced by the 'Nordic School', as is reflected in the title of this paper.

The respondents were asked about their perceptions of the practical aspects of marketing. They were asked to quantify their agreement with 14 statements, with the assumption that the higher the level of their agreement, the more representative the statement was for marketing (the 'marketing concept') from their perspective. Factor analyses were calculated based on the assumption that the 14 items were linked from the respondents' perspective. A four-factor solution was found to be appropriate both with respect to data summarisation and data reduction.

According to the perceptions of the respondents, 'Long-term focus' $\left(F_{1}\right)$ was the factor that was the most representative of 'the marketing concept'. This factor consisted of the following items: 'Marketing implies more focus on longterm profitability than short-term profits' $\left(\mathrm{I}_{14}\right)$, 'Marketing implies trust-building (in relationships) by keeping promises' $\left(\mathrm{I}_{11}\right)$, 'Marketing has a stronger ethical basis than sales' $\left(\mathrm{I}_{12}\right)$ and 'Regarding marketing, the focus is on developing long-term customer relationships' $\left(\mathrm{I}_{13}\right)$. According to the 'Nordic School', long-term marketing efforts are supposed to result in long-term business performance. The same way of thinking is also implicitly found in the new definition of marketing of the AMA as discussed above. Consequently, a 'Long-term focus' for marketing 
is found in both the AMA definition and in the 'Nordic School' approach.

'Marketing as sales' $\left(\mathrm{F}_{3}\right)$ was perceived as being least representative of 'the marketing concept'. This factor consisted of the following items: 'What theorists call marketing, practitioners call sales' $\left(\mathrm{I}_{8}\right)$, 'In practicality, there is no difference between marketing and sales' $\left(\mathrm{I}_{2}\right)$ and 'Marketing is a collective term for all efforts to increase sales volume' $\left(\mathrm{I}_{4}\right)$. This last item obtained the highest level (mean) when considering the individual statements. On average, however, the respondents did not perceive 'Marketing as sales' as representing 'the marketing concept' as closely as 'Long-term focus' did.

The four-factor solution included two other summated scales. 'Strategy and function' $\left(\mathrm{F}_{4}\right)$ consisted of: 'Marketing is closely related to corporate strategy, eg mission, vision, business ideas and business philosophy' $\left(\mathrm{I}_{1}\right)$, 'Marketing is a business function parallel to eg purchase and production' $\left(\mathrm{I}_{3}\right)$ and 'Marketing is closely related to profitability' $\left(\mathrm{I}_{5}\right)$. 'Reciprocity (Core)' $\left(\mathrm{F}_{2}\right)$ consisted of: 'Marketing implies reciprocity, ie both buyer and seller should be satisfied (buyer in terms of customer satisfaction and seller in terms of customer profitability)' ( $\left.\mathrm{I}_{9}\right)$, 'Marketing is closely related to customer satisfaction, customer loyalty and customer profitability' $\left(\mathrm{I}_{7}\right)$, 'Marketing implies that more importance is attached to profitability than to sales volume' $\left(\mathrm{I}_{10}\right)$ and 'Marketing, market orientation and customer orientation are synonymous concepts' $\left(\mathrm{I}_{6}\right)$.

Taking into consideration the findings regarding discriminant validity as discussed above, it seems as if respondents distinguished clearly between the four factors of the factor analysis. It should be underscored once more that $t$-tests for groups based on various criteria (industry, total revenue, number of employees and proportion of exports) did not reveal any significant differences. The conclusion was the same regarding both the four factors and the 14 items. Thus the results can probably be generalised to the two industries studied.

When analysing relationships between the four new variables (summated scales) and business performance as measured by 'Overall corporate performance', 'Reciprocity (Core)' $\left(\mathrm{F}_{2}\right)$ was the only significant variable. Inclusion of other explanatory variables in the regression equation (total revenue in the previous year, average number of workers in the previous year, proportion of exports (per cent) and a 'dummy' for industry) did not result in significant changes. Still 'Reciprocity (Core)' $\left(\mathrm{F}_{2}\right)$ was the only significant variable. This variable, however, which can be perceived as representing the 'core' of 'the marketing concept', cf. the literature review above, was not seen by respondents as being particularly representative of marketing. The majority of the respondents perceived this 'dimension' of marketing as being less representative than 'Long-term focus' and 'Strategy and function'. It should be noted that these findings cannot be looked upon as being exceptional. Significant relationships can be found between customer satisfaction, customer loyalty and customer profitability, as revealed in analyses from other studies. ${ }^{69,70}$ The approach here is, however, different, compared with various customer relationship analyses. This study offers various dimensions of 'the marketing concept' as explanatory variables in a regression model where business performance is the dependent variable. Owing to the statistical results regarding the relationship between 'Reciprocity (Core)' $\left(\mathrm{F}_{2}\right)$ and business performance, perhaps the practitioners should rethink their understanding of marketing?

The findings also indicate that profitability seems to be part of the summated scales or dimensions of 'the marketing concept'. This can be interpreted as showing that practitioners do want to be able to use financial metrics financial performance measures and financial accounts for customers, market segments, distribution channels - as decision supports for various decision situations (marketing processes and activities). ${ }^{71-73}$ Insight into the context of the business unit has a lot to say in the elaboration of market- and customer-oriented accounting systems. There may be different approaches in the same industry, just as in other areas of management accounting. ${ }^{74-76}$ Therefore, managers need to be fairly familiar with the context, and marketing practitioners should be involved in 
discussions of problem areas concerning marketoriented management accounting in a business unit. They should at a minimum be demanding with respect to market-oriented reports and graphical presentations, to ensure that decisionrelevant information is included and easily available. ${ }^{77-79}$

These findings have analogous implications for the academic world. Usually, the academic literature emphasises the importance of the 4-7 Ps regarding marketing (product, place, promotion, price, people, process and physical evidence). ${ }^{80}$ 'Profitability' is seldom included among those Ps. ${ }^{81-83}$ These findings also suggest that discussions of market- and customer-oriented financial models and financial performance metrics should be included in the syllabus of various marketing subjects.

The context for this research was the Norwegian furniture and fishing industries, but valuable contributions could come from analyses of other industries, both within and outside of a Nordic context.

The main results of this study showed that practitioners looked upon marketing ('the marketing concept') as being multidimensional. They identified four underlying factors (summated scales): 'Long-term focus' $\left(\mathrm{F}_{1}\right)$, 'Reciprocity (Core)' $\left(\mathrm{F}_{2}\right)$, 'Marketing as sales' $\left(\mathrm{F}_{3}\right)$ and 'Strategy and function' $\left(\mathrm{F}_{4}\right)$. The respondents perceived 'Long-term focus' $\left(\mathrm{F}_{1}\right)$ and 'Strategy and function' $\left(F_{4}\right)$ as representing 'the marketing concept' better than 'Reciprocity (Core)' $\left(\mathrm{F}_{2}\right)$ and 'Marketing as sales' $\left(\mathrm{F}_{3}\right)$. 'Reciprocity (Core)' $\left(\mathrm{F}_{2}\right)$ was, however, the only significant variable when the four summated scales were offered as explanatory variables for variations of business performance in regression models. 'Reciprocity (Core)' $\left(\mathrm{F}_{2}\right)$ was not perceived as being particularly representative for marketing among the practitioners, which suggests that practitioners might benefit from rethinking their understanding of 'the marketing concept', or at least reflect on the importance they attach to various processes of marketing. Profitability was also perceived to be part of various dimensions of 'the marketing concept', suggesting that the syllabus of various marketing subjects might benefit from the inclusion of market- and customer-oriented financial models and financial performance metrics. In this way the academic world could in the future contribute to increased insights on profitability for marketing practitioners. Additionally, marketing practitioners should be involved and engaged when market-oriented management accounting issues are discussed in a business unit. They should also be demanding with respect to market-oriented reports, in order to obtain the financial marketing metrics necessary for decision support. Thus the results from this study have implications both for academia and for the business world.

\section{References and Notes}

1 Shaw, E. H. and Jones, D. G. B. (2006) 'A history of schools of marketing thought', Marketing Theory, Vol. 5, No. 3, pp. 239-281.

2 Howard, C. A. (2003) 'The internationalization of the marketing discipline', Leadership in International Business Education and Research, Research in Global Strategic Management, Vol. 8, pp. 89-106.

3 Kinnear, T. C., Bernhardt, K. L. and Krentler, K. A. (1995) 'Principles of Marketing', 4th edn, HarperCollins Publishers, New York, NY

4 Smith, A. (1776/1937) 'An Inquiry into the Nature and Causes of the Wealth of Nations', Modern Library, New York. Smith observed that the division of labour is the fundamental organising principle of groups and society, and 'given a division of labour there must be exchange' (op. cit., p. 17).

5 Converse, P. D. (1945) 'The development of the science of marketing - An exploratory survey', Journal of Marketing, Vol. 10 (July), pp. 14-23.

6 Hunt, S. H. (1976) 'The nature and scope of marketing', Journal of Marketing, Vol. 40 ( July), pp. 17-29.

7 Shaw and Jones (2006) op. cit.

8 Wilkie, W. L. (1994) 'Consumer Behavior', 3rd edn, John Wiley \& Sons, Chichester.

9 Barksdale, H. C. and Darden, B. (1971) 'Marketers' attitudes toward the marketing concept', Journal of Marketing, Vol. 35 (October), pp. 29-36.

10 Keith, R. J. (1960) 'The marketing revolution', Journal of Marketing, Vol. 25 (January), pp. 35-38.

11 Blythe, J. (2005) 'Essentials of Marketing', 3rd edn, Prentice-Hall, Essex, UK.

12 American Marketing Association (1987) 'Marketing milestones of four decades reviewed', Marketing News, 31 July.

13 Kermally, S. (2003) 'Gurus on Marketing', Thorogood, London, UK.

14 Shaw and Jones (2006) op. cit.

15 http://en.wikipedia.org/wiki/Marketing.

16 Barksdale and Darden (1971) op. cit.

17 Wilkie (1994) op. cit.

18 Wilkie (1994) op. cit. p. 8. 
19 Kotler, P., Armstrong, G., Saunders, J. and Wong, V. (2002) 'Principles of Marketing', 3rd European edn, Pearson Education Ltd., Essex, UK.

20 Blythe (2005) op. cit.

21 Jobber, D. (2004) 'Principles and Practice of Marketing', 4th edn, McGraw-Hill International, Berkshire, UK.

22 Boyd Jr, H. W., Walker Jr, O. C., Mullins, J. and Larréché, J. C. (2002) 'Marketing Management: A Strategic Decision-Making Approach', McGraw-Hill, New York, NY.

23 Palmer, A. (2004) 'Introduction to Marketing: Theory and Practice', Oxford University Press, Oxford, UK.

24 Kotler, P. and Keller, K. L. (2006) 'Marketing Management', 12th edn, Pearson, Prentice-Hall, Upper Saddle River, NJ, USA.

25 Houston, F. S. (1986) 'The marketing concept: What it is and what it is not', Journal of Marketing, Vol. 50 (April), pp. 81-87.

26 Webster, F. E. (1992) 'The changing role of marketing in the corporation', Journal of Marketing, Vol. 56 (October), pp. 1-17.

27 Drucker, P. (1954) 'The Practice of Management', Harper \& Row, New York, USA. The quotation is from p. 37.

28 Houston (1986) op. cit.

29 A number of contributions can be found, with an overview in Langerak, F. (2003) 'An appraisal of research on the predictive power of market orientation', European Management Journal, Vol. 21, No. 4, pp. 447-464.

30 Felton, A. P. (1959) 'Making the marketing concept work', Harvard Business Review, Vol. 37 (July/August), pp. 55-65. The quotation is from p. 55.

31 Levitt, T. (1960) 'Marketing myopia', Harvard Business Review (July/August), pp. 45-56. The quotation is from p. 56.

32 McNamara, C. P. (1972) 'The present status of the marketing concept', Journal of Marketing, Vol. 36 (January), pp. 50-57. The quotation is from p. 51.

33 Ames, B. C. (1970) 'Trappings vs. substance in industrial marketing', Harvard Business Review (July/August), pp. 93-102. The quotation is from p. 95.

34 Webster, F. E. (1992) op. cit.

35 Some contributions are referred to elsewhere in the paper. Some other examples are: Hise, R. T. (1965) 'Have manufacturing firms adopted the marketing concept?' Journal of Marketing, Vol. 29 ( July), pp. 9-12.

36 Konopa, L. J. and Calabro, P. J. (1971) 'Adoption of the marketing concept by large Northeastern Ohio manufacturers', Akron Business and Economic Review, Vol. 2 (Spring), pp. 9-13.

37 Webster, F. E. (1988) 'The rediscovery of the marketing concept', Business Horizons (May/June), pp. 29-39.

38 Hooley, G. J., Lynch, J. E. and Shepherd, J. (1990) 'The marketing concept: Putting the theory into practice', European Journal of Marketing, Vol. 24, No. 9, pp. 7-24.

39 Moorman, C. and Rust, R. T. (1999) 'The role of marketing', Journal of Marketing, Vol. 63 (Special Issue), pp. 180-197.

40 Francke, N. and Mazanec, J. A. (2005) 'The six identities of marketing: A vector quantization of research approaches', European Journal of Marketing, Vol. 40, No. 5/6, pp. 634-661.

41 The formulation of the former definition from 1985 was as follows: "Marketing is the process of planning and executing the conception, pricing, promotion and distribution of ideas, goods and services to create exchange and satisfy individual and organizational objectives'.

42 Yeung, M. C. H., Ging, L. C. and Ennew, C. T. (2002) 'Customer satisfaction and profitability: A reappraisal of the nature of the relationship', Journal of Targeting, Measurement and Analysis for Marketing, Vol. 11, No. 1, pp. 24-33.
43 Helgesen, Ø. (2006a) 'Are loyal customers profitable? Customer satisfaction, customer (action) loyalty and customer profitability at the individual level', Journal of Marketing Management, Vol. 22, pp. 245-266.

44 Blythe (2005) op. cit., p. 2.

45 Egan, J. (2004) 'Relationship Marketing: Exploring Relational Strategies in Marketing', 2nd edn, Pearson Education Limited, Essex, UK.

46 Grönroos, C. (1994) 'From marketing mix to relationship marketing: Towards a paradigm shift in marketing', Management Decisions, Vol. 32, No. 2, pp. 347-360.

47 Helgesen, Ø. (2006b) 'Customer segments based on customer account profitability', Journal of Targeting, Measurement and Analysis for Marketing, Vol. 14, No. 3, pp. 225-237.

48 Clark, B. (1999) 'Marketing performance measures: History and interrelationships', Journal of Marketing Management, Vol. 15, pp. 711-732.

49 Lambin, J. -J. (1993) 'Strategic Marketing. A European Perspective', McGraw-Hill Book Company Europe, Maidenhead, Berkshire, UK.

50 Solomons, D. (1952). Studies in Costing', Sweet \& Maxwell Ltd., London, UK.

51 Parker, R. H. (1980) 'History of accounting for decisions', in Arnold, J.A., Carsberg, B.V. and Scapens, R.W., (eds), ' Topics in Management Accounting', Philip Allan Publishers Ltd., Deddington, Oxford, UK, pp. 262-276.

52 Venkatraman, N. and Ramanujam, V. (1986) 'Measurement of business performance in strategy research: A comparison of approaches', Academy of Management Review, Vol. 11, No. 4, pp. 801-814.

53 Venkatraman, N. and Ramanujam, V. (1987) 'Measuring of business economic performance: An examination of method convergence', Journal of Management, Vol. 13, No. 1, pp. 109-122.

54 Kaplan, R. S. and Norton, D. P. (1996) 'The Balanced Scorecard', Harvard Business School Press, Boston, MA, USA.

55 Kaplan, R. S. and Norton, D. P. (2001) 'The Strategy-Focused Organization: How Balanced Scorecard Companies Thrive in the New Business Environment', Harvard Business School Press, Boston, MA, USA.

56 Rucci, A. J., Kirn, S. P. and Quinn, R. T. (1998) 'The employeecustomer-profit chain at sears', Harvard Business Review (January/February), pp. 83-97.

57 Kaplan, R. S. and Norton, D. P. (2004) 'Strategy Maps: Converting Intangible Assets to Tangible Outcomes', Harvard Business School Press, Boston, MA, USA.

58 Kaplan and Norton (2004) op. cit.

59 Rucci, et al. (1998) op. cit.

60 Dess, G. G. and Robinson Jr, R. B. (1984) 'Measuring organizational performance in the absence of objective measures: The case of the privately-held firm and Conglomerate Business Unit', Strategic Management Journal, Vol. 5, pp. 265-273.

61 Venkatraman and Ramanujam (1986) op. cit.

62 Venkatraman and Ramanujam (1987) op. cit.

63 Dess and Robinson (1984) op. cit.

64 Venkatraman and Ramanujam (1986) op. cit.

65 Venkatraman and Ramanujam (1987) op. cit.

66 Hair Jr, J. F., Black, W. C., Babin, B. J., Anderson, R. E. and Tatham, R. L. (2006) 'Multivariate Data Analysis', 6th edn, Prentice-Hall, Upper Saddle River, NJ.

67 Hair, et al. (2006) op. cit.

68 Cohen, J. (1988) 'Statistical Power Analysis for the Behavioral Sciences', Erlbaum, Hillsdale, NJ. 
69 Zeithaml, V. A. (2000) 'Service quality, profitability, and the economic worth of customers: What we know and what we need to learn', Journal of the Academy of Marketing Science, Vol. 28, No. 1, pp. 67-85.

70 Helgesen (2006a) op. cit.

71 Best, R. J. (2005) 'Market-Based Management: Strategies for Growing Customer Value and Profitability', International edn, Pearson Education Inc., Upper Saddle River, NJ.

72 Doyle, P. (2000) 'Value-Based Marketing: Marketing Strategies for Corporate Growth and Shareholder Value', John Wiley \& Sons Ltd., West Sussex, UK.

73 Ward, K. (1992) 'Strategic Management Accounting', Butterworth Heinemann Ltd., Oxford, UK.

74 Garrison, R. H., Noreen, E. W. and Seal, W. (2003) 'Management Accounting', European edn, McGraw-Hill Education, Berkshire, UK.

75 Foster, G. and Gupta, M. (1994) 'Marketing, cost accounting and management accounting', Journal of Management Accounting Research (Autumn), pp. 43-77.
76 Cooper, R. and Kaplan, R. S. (1991) 'The Design of Cost Management Systems. Text, Cases, and Readings', Prentice-Hall, Englewood Cliffs, NJ, USA.

77 Best (2005) op. cit.

78 Ambler, T. (2003) 'Marketing and the Bottom Line: The Marketing Metrics to Pump Up Cash Flow', Second edn, Pearson Education Inc., London.

79 Abdel-Kader, M. and Luther, R. (2006) 'Management accounting practices in the British food and drinks industry', British Food Journal, Vol. 108, No. 5, pp. 336-357.

80 Blythe (2005) op. cit.

81 Petro, T. M. (1990) 'Profitability: The fifth 'P' of marketing', Bank Marketing (September), pp. 48-52.

82 Rust, R. T., Zeithaml, V. A. and Lemon, K. N. (2000) 'Driving Customer Equity: How Customer Lifetime Value is Reshaping Corporate Strategy', The Free Press, New York, NY.

83 Johnson, M. D. and Gustafsson, A. (2000) 'Improving Customer Satisfaction, Loyalty, and Profit: An Integrated Measurement and Management System', Jossey-Bass Inc., San Francisco, CA. 